\title{
An Instructional Tool for Grade VI Mathematics: A Mobile Application
}

\author{
April Joy P. Dee \\ San Carlos College \\ SCC, Pangasinan, Philippines
}

\author{
Kevin R. Ellorda \\ San Carlos College \\ Urbiztondo, Pangasinan, \\ Philippines
}

\author{
Bill John C. Salvador \\ San Carlos College \\ Calasiao, Pangasinan, Philippines
}

\author{
Jenniea A. Olalia \\ San Carlos College
}

\author{
Romulo L. Olalia Jr. \\ San Carlos College
}

\begin{abstract}
This study can be summarized that the use of mobile applications strongly follows a learning and therefore also a teaching strategy. Studies, discussions, and review of the literature discussed in this study implicate that school mathematics demands substantial change. It also suggests coordination of curriculum, instructional and resource materials, teaching methodologies, and grades; school organization should drive the changes. An Instructional Tool for Grade VI Mathematics: A mobile application offers an action for changing mathematics education. The study aimed to design and develop a mobile application that would help the teachers in their math instruction and the students in their math learning. The developed mobile application was put into use by a Grade VI section in Central I Elementary School to purposely evaluate its effectiveness and usability.
\end{abstract}

\section{Keywords}

Android OS, Comparison Group, Effectiveness (students), Effectiveness (teacher), Experimental Group, Flashcards, Functionality, Instructional Tool, Mobile Application, Operating System, Resource Material, Student's grade, Software Development Life Cycle (SDLC), Teaching Methodology, Usability, VI-FCP, VI-CM, Waterfall Model.

\section{INTRODUCTION}

When Sesame Street first came out in the late 60's, people did not believe that you could teach through a non-traditional medium like television. They said that the experience could not be tailored well enough; that television was the opposite of education - a mind numbing activity made by the people in Hollywood. Nevertheless, the advantages and possibility that existed in what could come of a successful educational television show were too great. The approach was the major boon - the capacity to teach children in every household with a television at the flip of a switch. Ultimately as proponents know, Sesame Street became paradigm of interaction for learning that changed education forever.

During $6^{\text {th }}$ grade, mathematics students are introduced to knowledge of word names and standard numerals for whole numbers, fractions, decimals through hundred thousands, and percent's. Many students struggle in Grade VI mathematics, as ust introduces larger numbers and more complicated formulas, these issues can often emerge around the end of elementary school.

In the latest Third International Mathematics and Science Study-Repeat the Filipino students garnered a score of 350 in mathematics, way below the international average of 489
(Philstar Global) [1]. In the 2012 National Achievement Test for Grade 6, sixth grade public school pupils scored a mean percentage score of 66.7 lower than the previous year where they scored 68 and did not even reach the mean score goal set by DepEd, which is 75\% (DepEd) [2]. While in 2007 National Diagnostic Test for Grade VI Public School only half a percent or $0.52 \%$ (6,500 KIDS) of sixth grade public schools in the Philippines scored higher than $75 \%$ in mathematics (Marketmanila) [3]. Indeed, the students are still low in mathematics education.

Central I Elementary School, most popular public school in San Carlos City, Pangasinan, is keen on quality assurance and maintenance of standards. One of its major problems is its grade VI comprehension of the complex topics in grade VI mathematics, which is evident in the results of the school's standardized quarterly tests. Based on the interview conducted to the faculty members under Mathematics Department they noted that while some students perform highly, others, on the contrary, do not perform well. They are concerned about those who do not perform well because if this poor performance goes unchecked, the school may lose its reputation.

Many pupils are considered underachievers in mathematics. They fall below their expected level of mathematics achievement for a variety of reasons. When asked why they were not as successful in learning mathematics, many people reply that they "never understood mathematics," or "never liked it because it was too abstract and did not relate to them." Based on the findings, pupil factors such as study habits, time management, and attitude towards mathematics are the factors that affect underachievement in mathematics.

Going to school is a daily routine. Well, using technology is a daily routine for most students and people in general. Adults, let alone students, scroll through their cell phones as soon as they wake up. A research from Common Sense Media revealed the exceptional increase of children using gadgets such as smartphones and tablets have increased in just two years. From 38\% in 2011, the biannual survey revealed that children below eight-year-old using mobile devices have gone up to $72 \%$ in 2013 (C.S.M, 2013) [4]. Technology is becoming more social, adaptive, and customized, and as a result, it can be an amazing teaching tool.

Mobile learning apps are a delivery format that provides learners with the flexibility to learn anywhere, anytime, even without internet connection. A mobile learning app lets you view your learning content offline from your mobile device. Typical examples of the devices used for mobile learning 
include cell phones, smartphones, tablet PCs, laptops.

To help the pupils perform better in their mathematics subject, the proponents propose a mobile application. The application is a tool for supporting teacher's in-class instruction. It can be a huge help for pupils, not only for those who are less interested in learning mathematics but also for those who have a hard time understanding their mathematics lessons. It is fun, educational, and portable.

This learning platform will give teachers the ability to accommodate different learning styles by incorporating visual and audio into their lessons and to connect students to resources and tools that will help them better understand classroom material and enhance learning through integrating application that will amplify their lesson plans. This application will provide a better student experience, one where they will be able to gain mathematics learning through watching videos and flash cards of their topics and hone their mathematics skills through sets of mathematics exercise. This will make the pupils' technology time productive, educational and fun eventually leading to good grades.

\subsection{Project Framework}

The proponents prepared a project framework that served as the basis of the study shown in figure 1. The Operational Paradigm (Figure 1) defines the inputs, process and output of the progress of the study.

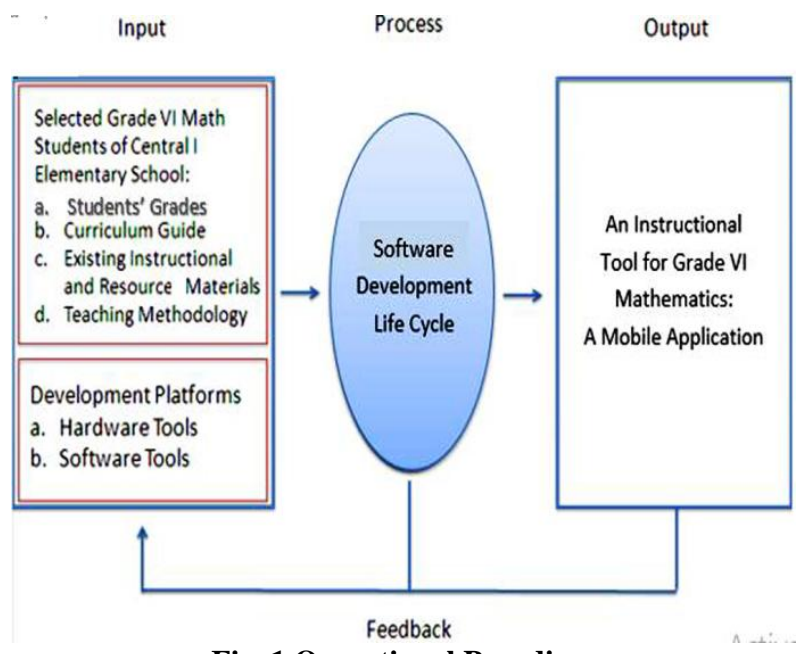

Fig. 1 Operational Paradigm

Before creating the application, the proponents will gather all the data and requirements needed for the proposed study. First, the proponents need to know about the state of the grade VI pupils of Central I Elementary School in mathematics from their performance or grades. For the outline of the proposed mobile application, the proponents will follow DepEd's curriculum guide as their reference.

And for the content, it will be acquired from the existing instructional and resource materials being used in Grade VI, Central I Elementary School. The proponents will also use the traditional teaching methodology as an input to develop strategies for an effective mobile learning application. In order to develop actual application, the proponents need to acquire hardware and software tools like computer, mobile device, internet, video editor, photo editor, and mobile application development tools.

Upon the overall development process of the mobile application the proponents will use SDLC. Every software is different and requires a suitable SDLC approach. To ensure the process of development, the proponents will be implementing waterfall model because of its simplicity and stability. Aside from those, the proponents chose SDLC because it allows departmentalization and control. Where in a schedule can be set with deadline for each stage of the development. Therefore, the proponents need to be accurate and critical with the analysis of the study, and must have a clear concept of the requirements before the actual development of the application for it does not allow iteration until the last stage is done.

After the application is built it will go through testing to resolve any issues within the source code, as well as user's acceptance testing where the users vet the software and give their feedback. If changes are needed to be made, the proponents will return at the top of the process cycle until the application meets all the requirements and users are satisfied with the functionality of the application.

\section{REVIEW OF RELATED LITERATURE}

Today, people are literally surrounded by technology everywhere they go. Technology has always flourished for the gain of mankind. The major achievements of technology have left man spell-bound and every part of the world today is enjoying the comforts provided by technology (Lavin, et al) [5]. Modern technology has greatly improved people's lives through different fields such as medicine, work, education and industry. These technologies take many forms such as personal computers, smart phones, the internet, web and mobile phone applications, digital assistants, and cloud computing. There's no denying that these technological devices have become a significant part of students' everyday lives (PUP) [6]. With the growing availability of technology, people can have a great impact on learning. This will give students great resources to improve learning and could encourage them become more responsible.

The prevalent daily use of technology in people's lives overall makes the use of technology very relevant to the students and provides a connection that will greatly benefit student learning (Costley) [7]. Because technology is a big part of people's daily lives, it is pertinent that children learn how to use it at an early age (Purcell, et al) [8]. Many children today have access to a great deal of technology in their home. Technology is being used by children on a daily basis by way of web surfing, texting, social networking, interactive games, and in more ways. This access will result in students being comfortable by using technology at school as well (Rikala) [9]. Technology can change the way children think, what they learn, and how they interact with peers and adults. (Bickham) [10]. The authors show that everyone can achieve learning through technology. When children use technology tools in elementary schools, a sense of confidence and competence in their computer skills will grow as they get older it has a great impact to the society most importantly to the students hence they can use mobile phone as their gateway in helping them in their studies, making the proponents' study feasible.

When elementary school teachers use and model different forms of technologies, they actively engage their students and create a stimulating work environment (Kenney) [11]. Technology provides meaningful learning experience by making it interesting, enjoyable, and interactive. Children today love to learn by doing, interacting, and discovering (Ayas) [12]. Technology also provides hands-on learning opportunities that can be integrated into all school curricular areas, including mathematics, reading, science, and social 
studies as well as other academic subjects (Bulut \& Delen) [13]. With technology learning moving more and more outside of the classroom and into the learner's environment, both real and virtual, thus becoming more situated, personal, and interactive.

Students today require stronger mathematical knowledge, skills and values to pursue higher education, to compete and be part of the technologically oriented workforce and to be informed citizens. The goal of mathematics education is to develop a mathematically empowered citizenry. For Filipino students, the goal of Mathematical Empowerment focuses on developing critical and analytical thinking skills among all Filipino students (Vistro) [14]. "Students must be fluent in arithmetic computation -- they must have efficient and accurate methods, and understand them. Students should know their basic addition, subtraction, multiplication and division combinations" (Yang) [15]. As the proposed study is an instructional tool for mathematics, it was vital for the proponents to know the concepts of mathematics for them to create an effective tool for their learning that will be helpful for the teachers' mathematics instruction and learning.

\section{PROJECT DESIGN AND METHODOLOGY}

Methodology is a term used to describe a process, technique or manner in which an action is performed. Under the development of a system, a methodology refers to the process that will be taken to ensure that the software is effectively and efficiently developed. The purpose of project methodology is to allow a process for controlling the entire management process through effective decision making and problem solving, while ensuring the success of specific processes, approaches, techniques, methods and technologies (Humanities Teaching Learning Office).

Research design "provides the glue that holds the research project together" (Trochim) [16]. A design is used to structure the research, to show how all of the major parts of the research project work together to try to address the central research questions. To complete an accurate assessment of the proposed study the proponents determine the type of approach necessary, which is descriptive research.

Descriptive studies are usually the best methods for collecting information that will demonstrate relationships and describe the world as it exists. The proponents used descriptive research in order to have a clear concept of the learning environment in mathematics of the grade VI pupils of Central 1 Elementary School. The proponents explored the entities involved in the mathematics learning environment to be able to describe the problems they are dealing with, organize the findings in order to explain why these problems are needed to be addressed, validate the existence of the problems in order to develop a solution.

When developing a software, software development lifecycle (SDLC) is a common methodology for software development. SDLC offers a clear idea on what should be or should not be built, since everything will be laid out before a single code is written, the goal is clear and could be implemented on time. With an SDLC Model, programs built will have a clear documentation of development, structure and even coding which is why the proponents followed this method in the development of the proposed study. In the SDLC process the proponents carefully studied the current software where the requirements are determined, studied the structural requirements and eliminated redundancies, and designed all aspects of the software.

\section{PRESENTATION AND ANALYSIS OF DATA}

In this chapter, the data gathered from Central I Elementary School are presented. This chapter discusses results of the data analysis, and interpretation of the results from the conducted experiment and survey. The discussion corresponds to the phases of the selected Software Developmental Lifecycle.

\subsection{Software Developmental Life Cycle}

The Software Development Life Cycle (SDLC) is a conceptual model used in project management that describes the stages involved in an information system development project, from an initial feasibility study through maintenance of the completed application. SDLC ensures clear documentation of development, structure and even coding. This is why it is important for the proponents to utilize the laid out plans or steps of SDLC to ensure the usability of the mobile application to be created and the success of the study. Selection of appropriate Software Development Life Cycles can increase project success. Depending on the selected Life Software Development Cycle (SDLC), one can decrease development time/cost, minimize overhead and risk exposure, manage uncertainty, improve quality, promote client relations, and provide better project tracking and control. Despite the benefits of using suitable SDLCs, it is generally difficult to select the most appropriate one.

\subsection{Criteria in Selecting a Software Developmental Life Cycle Model}

One of the key features of selecting a process model is to understand the project in terms of size, complexity, and so on. In addition, the risks which are associated with the project should also be considered. The proponents set criteria based on project type and associated risks, requirements of the project, and the users required to select the most suitable process model.

As shown in table 1, Modified Waterfall with a total average of 2.67, earned the highest score over the models discussed. A tie between V-Shaped, and Iterative and Incremental are second with each having an average of 2.5 being so close with the highest scored model. Spiral being second to the least while, the least model is Agile with an average of 1.67.

Table 1 - Decision Matrix

\begin{tabular}{|c|c|c|c|c|c|}
\multicolumn{1}{|c}{ Table 1 - Decision Matrix } \\
\hline Factors & $\begin{array}{c}\text { Modifi } \\
\text { ed } \\
\text { Waterf } \\
\text { all }\end{array}$ & $\begin{array}{c}\text { V- } \\
\text { Shape } \\
\text { d }\end{array}$ & $\begin{array}{c}\text { Spir } \\
\text { al }\end{array}$ & $\begin{array}{c}\text { Iterative } \\
\text { and } \\
\text { Increme } \\
\text { nt }\end{array}$ & Agile \\
\hline $\begin{array}{c}\text { Stable } \\
\text { Requirement } \\
\text { and Scopes }\end{array}$ & 2 & 2 & 2 & 2 & 2 \\
\hline $\begin{array}{c}\text { Reliable } \\
\text { System }\end{array}$ & 2 & 2 & 3 & 2 & 2 \\
\hline $\begin{array}{l}\text { Strong } \\
\text { Project } \\
\text { Manageme } \\
\text { nt }\end{array}$ & 3 & 3 & 3 & 3 & 3 \\
\hline $\begin{array}{l}\text { Inexperienc } \\
\text { e Project } \\
\text { Team }\end{array}$ & 3 & 2 & 1 & 2 & 1 \\
\hline Documentat & 3 & 3 & 2 & 3 & 1 \\
\hline
\end{tabular}




\begin{tabular}{|l|c|c|c|c|c|}
\hline ion & & & & & \\
\hline $\begin{array}{l}\text { Component } \\
\text { Reusability }\end{array}$ & 3 & 3 & 1 & 3 & 1 \\
\hline $\begin{array}{l}\text { Total } \\
\text { Average }\end{array}$ & 2.67 & 2.5 & 2 & 2.5 & 1.67 \\
\hline
\end{tabular}

Description: The table shows the mapping of criteria between different models.

Legend:

$$
\begin{aligned}
& 0-1.49=\text { Good } \\
& 1.5-2.49=\text { Very Good } \\
& 2.5-3.0=\text { Execellent }
\end{aligned}
$$

\subsubsection{Organizational Chart with Functions}

Central Elementary School Organizational Chart (shown in Figure 2) illustrates relations between faculty and staff within the school. At the head of the chart is the principal, and the others below are the guidance counselor, head teacher, and math teachers, in the order of their rank.

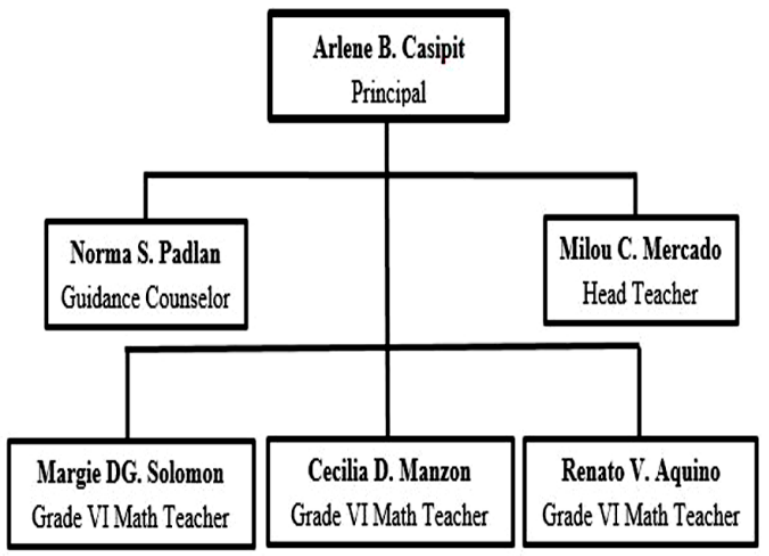

Fig. 2 Central Elementary School Organizational Chart

\section{Principal}

The principal, Mrs. Arlene B. Casipit, is the administrative and professional leader of the school. She manages the day-today activities of Elementary School. She oversees faculty and staff and make decisions that impact the overall educational success of the school.

\section{Head Teacher}

Head teacher, Mr. Milou C. Mercado, is secondary to the principal with regards to school governance. He handles student discipline, curriculum, student council or student activities.

\section{Guidance Counselor}

Guidance counselor, Mrs. Norma S. Padlan, offers advice on problems, helps troubled students and assists students in making career or plans.

\section{Math Teacher}

Math teacher bestows students with arithmetic and problemsolving skills. $\mathrm{He} /$ she helps pupils develop critical-thinking abilities by gaining an understanding of mathematic concepts.

\section{Findings}

Based on the observation and gathered information, the proponents found out that most of the grade VI students have low grades in their math subject. In a grade VI section in Central I Elementary School, the number of pupils above the mean average of 84 are outnumbered by the number of pupils that below the average with a ratio of 9:17. According to the first quarter of Deped's curriculum guide for grade VI, the pupils are introduced to the four fundamental operations involving fractions and decimals. To facilitate mathematics learning, the teachers act as demonstrator while, to support their instruction, they use PowerPoint presentations and for their reference they still use textbooks from the previous DepEd program due to delayed delivery of the new ones.

\section{SUMMARY, CONCLUSION, AND RECOMMENDATION}

This chapter presents the overall summary and findings, the conclusions drawn and the proponents' recommendation.

The aim of this study is to develop a Mobile Application that would serve as instructional tool for grade VI mathematics and eventually help the pupils get high scores in their mathematics tests. It is an interactive user-friendly application that the pupils can use it without requiring much supervision from their parents and teachers.

Central I Elementary School measures relative quality of a pupil's work in his/her class activity, attendance, participation, assignment, quizzes and examination with 65100 grade/mark. The teachers record their daily lessons/activities during class in their Daily Lesson Log. According to the Deped's curriculum guide for grade VI, the first quarter covers number and number sense where the pupils are introduce to the four fundamental operations involving fractions and decimals. During math class the teacher acts as a demonstrator, he/she shows students what they need to know, and at the same time a facilitator, he/she also promotes self-learning. Then to assess the students' comprehension, the teacher gives the students set of math problems. Central I Elementary School has some existing instructional tools to support in-class instruction. DepEd has issued different instructional tools to support math instruction but teachers prefer using PowerPoint presentations instead. In addition, for their reference, $\mathrm{k}-12$ books are not yet available that is why they still use the old books.

From the findings that majority of the grade VI students are low in their mathematics grades and the instructional and resource materials are less than the needs of the students, what have been factually learned are; that the inadequate instructional and resource materials contributes to why majority of the students have low grades in mathematics. Also, the complexity of the topics under the Grade VI k-12 curriculum guide adds up to why students are low in their mathematics tests. Therefore, teachers need to muster and deploy a wide range of resources to support the acquisition of mathematical knowledge. Although teachers need a range of resources, teaching is very much a problem-solving activity. The representations, activities, and teaching methodologies in the teachers' classrooms engage teachers how to plan their instruction to foster the development of students' mathematical thinking.

\section{REFERENCES}

[1] Philstar Global (N.D), Filipino Students Still Rate Low In Math.

[2] Deped, (2013). K To 12 Curriculum Guide Art .

[3] Market Manila, 2012. Retrieved April 21, 2017.

[4] Common Sense Media, 2013. Retrieved April 21, 2017 From Http://Scholarscompass.Vcu.Edu/Cgi/Viewcontent.Cgi? 
Article $=4826 \&$ Context=Etd/Sei_Mathbasic.Pdf.

[5] Angeline M. Lavin, Leon Korte \& Thomas L. Davies (2011). Journal Of Technology Research: The Impact Of Classroom Technology On Student Behavior: April 2011 65-77. Vol. 2 From. Retrieved May 07, 2017 From Http://Www.Aabri.Com/Manuscripts/10472.Pdf.

[6] Polytechnic University Of The Philippines- Bansud Campus (October 09, 2013) The Effects Of Technological Devices To The Learning Performance Of Information Technology Students.

[7] Kevin C. Costley, Ph.D. (October, 2014). The Positive Effects Of Technology On Teaching And Student Learning.

[8] Kristen Purcell, Et. Al. (February 28, 2013). How Teachers Are Using Technology At Home And In Their Classrooms. Retrieved May 09, 2017 From Http://Www.Pewinternet.Org/2013/02/28/How-

Teachers-Are-Using-Technology-At-Home-And-InTheir-Classrooms/.

[9] Jenni Rikala (2/2013). Reports Of The Department Of Mathematical Information Technology: Series E. Educational Technology Retrieved May 09, 2017 From Asee Southeast Section Conference The New Frontier Of Education.

[10] Mona Bickham, Frances Bradburn, Richard Edwards, Et. Al (2012). Teaching Today's Students On Their Terms: International Education Advisory From Board. Retrieved May-09,2017

From Https://Www.Certiport.Com/Portal/Common/Documentl ibrary/Ieab_Whitepaper040808.Pdf.
International Journal of Computer Applications (0975 - 8887)

Volume 180 - No.11, January 2018

[11] Kenney, L. (2011). Elementary Education, There's An App For That: Communication Technology In The Elementary School Classroom. The Elon Journal Of Undergraduate Research In Communications. Retrieved May-09,2017 From Http://Www.Elon.Edu/Docs/Eweb/Academics/Communi cations/Research/Vol2no1/07kenney.Pdf

[12] Baytak, A., Tarman, B., \& Ayas, C. (2011). Experiencing Technology Integration In Education: Children's Perceptions: International Electronic Journal Of Elementary Education. Retrieved May 09, 2017 From Http://Www.Iejee.Com/Index/Makale/140/ExperiencingTechnology-Integration-In-Education-ChildrensPerceptions.

[13] Bulut, O., \& Delen, E. (2011). The Relationship Between Students' Exposure To Technology And Their Achievement In Science And Math: The Turkish Online Journal Of Educational Technology. Retrieved May 09, 2017 From Https://Eric.Ed.Gov/?Id=Ej945004.

[14] Catherine P. Vistro-Yu, Ed.D. (2011). Mathematics Framework For Philippine Basic Education. Retrieved May-09,2017 From Http://Www.Sei.Dost.Gov.Ph/Images/Downloads/Public.

[15] Wei-Chi Yang, Ph.D. (2015). Mathematics Education Reform In The East And The West Technology Issues: Reform In The East And The West Technology Issues.

[16] William M.K. Trochim, 2005, Design. Retrieved May 14,2017 From Https://www.Socialresearchmethods.Net/Kb/Design.Php. 